\title{
JEJAK ORANG MELAYU SEBAGAI PENYEBAR AGAMA ISLAM DI KERAJAAN GOWA-TALLO
}

\section{The Tracks Of The Malay People as The Islam Dusseminator in Gowa - Tallo Kingdom}

\author{
Muhaeminah dan Makmur
}

Balai Arkeologi Makassar

Jln. Pajjaiyang No. 13 Sudaing Raya Makassar

Email: minbalar@gmail.com dan makmurdpmks@gmail.com

Naskah diterima tanggal 31 Juli 2015. Naskah direvisi tanggal 06 Agustus 2015. Naskah disetujui tanggal 02 November 2015.

\begin{abstract}
Abstrak
Kehadiran orang Melayu pada awal abad XVI M untuk berdagang dan menyebarkan agama Islam di Kerajaan Gowa-Tallo pasca kejatuhan Malaka oleh bangsa Portugis terekam di dalam naskah lontara Kerajaan Gowa dan Wajo. Rekam jejak Islamisasi Kerajaan Gowa-Tallo oleh orang Melayu menarik untuk dikaji dalam perspektif arkeologis. Penelitian menggunakan metode kualitatif, dengan data bersumber dari catatan lapangan, rekaman fotografi, naskah lontara, data pustaka, dan hasil wawancara, menggunakan strategi penelitian lapangan, yaitu survei, ekskavasi dan wawancara. Analisis data menggunakan pendekatan induktif, deskriptif, dan tipologis. Sebaran temuan arkeologis berupa masjid dan makam kuno telah memberikan petunjuk tentang daerah okupasi orang Melayu, fase-fase permukiman orang Melayu, dan fase Islamisasi Kerajaan Gowa-Tallo oleh orang Melayu.
\end{abstract}

Kata kunci: Orang Melayu, Islam, Kerajaan Gowa-Tallo, arkeologi

\section{Abstract}

The presence of the Malays in the early sixteenth century AD to trade and the spread of Islam in the kingdom of Gowa-Tallo after the fall of Malacca by the Portuguese recorded in the text lontara Kingdom of Gowa and Wajo. Islamization track record by a Malay kingdom of Makassar interesting to study the archaeological perspective. Research using qualitative methods, with the data derived from field notes, recording photography, script lontaraq, literature data and the results of interviews, field research strategy, which surveys and interviews. Analysis of data using an inductive approach, descriptive, and typological. The distribution of archaeological finds such as mosques and ancient tombs have provided clues about occupational area of the Malays, the phases of the settlement of the Malays, and the phase of Islamization Kingdom of Gowa-Tallo by the Malays.

Keywords: Malays, Islam, the Kingdom of Gowa-Tallo, archaeology

\section{PENDAHULUAN}

$\mathrm{K}$ erajan Gowa-Tallo merupakan kerajaan yang mempunyai pengaruh terbesar di hal itu hingoa kini masih biasa kita lihat, melalui peninggalan arkeologi berupa benteng, mesjid, makam, senjata, alat-alat rumah tangga, naskah kuno dan sebaran daerah pemukiman penduduk yang luas.

Fase awal perkembangan Kerajaan Gowa dimulai dari pra tomanurung di mana Kerajaan Gowa terdiri dari sembilan kelompok masyarakat yang dinamakan Bate Salapang yaitu: Tombolo, Lakiung, Parang-Parang, Data, Agang Jene, Bissei, Kalling dan Se'ro. Mereka hidup di wilayah masing- 
masing, namun seiring dengan perkembangan mereka saling berperang antara satu dengan yang lain, sehingga terjadi kekacauan, hingga pada suatu saat muncul seorang perempuan yang dipersepsikan oleh masyarakat pada masa itu sebagai orang yang turun dari langit sehingga dinamakan sebagai To Manurung, menjadi pemersatu dan pemimpin Bate Salapang (Harkantiningsih, 2008:14). Dengan diangkatnya To Manurung menjadi pemimpin mereka, pada masa itupula Bate Salapang dilebur menjadi Kerajaan Gowa, yang diperkirakan pada abad ke 13 (Poelinggomang, 2004: 27).

Fase kemajuan Kerajaan Gowa, ketika terjadi pemindahan pusat kerajan, dari Tamalate ke Somba Opu oleh Karaeng Tumaparissi Kalonna Raja Gowa ke-9 (1510-1546). Hal ini menandakan adanya perubahan orientasi kerajaan dari agraris ke maritim, dimana Kerajaan Gowa ingin menguasai pusat perniagaan dan pelabuhan karena pada akhir abad ke-15 telah ramai dikunjungi pedagang dari Jawa dan Malaka. Kerajaan Tallo yang telah lama bergelut dalam dunia perniagaan, sehingga Karaeng Tumaparissi Kalonna merasa tersaingi, dan melakukan serangan terhadap Kerajaan Tallo, peperangan ini berakhir dengan perjanjian yang berisi sumpah untuk menyatukan dua kerajaan. Berbunyi: Barang siapa yang mengadu domba Gowa dan Tallo akan dikutuk oleh dewata. Sejak itu dikenal ungkapan "satu rakyat dua raja", hingga dikenal pula menjadi kerajaan kembar Gowa-Tallo (Poelinggomang, 2002: 23-24).

Fase kemunduran Kerajaan Gowa-Tallo ketika kemenangan berpihak ke sekutu Kerajaan Bone dan Belanda (VOC) yang berakhir dengan perjanjian Bungaya pada tanggal 18 November 1667. Perjanjian tersebut sangat menguntukan pihak Belanda, dimana Kerajaan Gowa-Tallo membayar kerugian perang (pasal 13), melepas seluruh tawanan pegawai VOC (pasal 2), menyerahkan barang VOC yang disita (pasal 3), melepas daerah jajahan kerajaan (pasal 14 dan 16 hingga 21), membongkar benteng pertahanannya (pasal 10), mengusir semua bangsa Eropa yang berdagang di Makassar (pasal 6), melarang orang Makassar berlayar ke Maluku (pasal 9), hanya membolehkan VOC yang berdagang di Makassar tanpa macam-macam kewajiban (pasal 8), dan menyerahkan Benteng Ujung Pandang berikut perkampungan dan lingkungannya kepada VOC (pasal 11) (Poelinggomang, 2002: 35).

Kajian kesejarahan terkait dengan Kerajaan Gowa-Tallo telah banyak dilakukan oleh kalangan akademisi baik dari dalam dan luar negeri, sehingga informasi tentang asal-usul Kerajaan GowaTallo hingga masa kejayaan sampai runtuhnya, cukup banyak ditemukan. Begitu pula penelitian kearkeologian telah banyak dilakukan baik instansi pemerintah seperti Balai Pelestarian Cagar Budaya (BPCB) yang telah melakukan pemeliharaan dan pelastarian peninggala Kerajaan Gowa Tallo berupa benteng, kompleks makam dan mesjid. Balai Arkeologi Makassar juga berulang kali penelitian arkeologi, seperti pada tahun 2006 melakukan survei dan ekavaksi Benteng Garassi sebagai bagian dari wilayah Kerajaan Gowa-Tallo, untuk mengetahui lapisan budaya dan pola pemukiman Benteng Garassi (M. Irfan Mahmud dkk, 2006). Pusat Arkeologi Nasional pada tahun 2007 dan 2008 juga melakukan penelitian arkeologi di wilayah Kerajaan Gowa-Tallo, dengan tujuan pertama: mengetahui bentuk atau pola keadaan fisik dari kota dan huniannya, kedua: fungsi dan aktivitas kota, dan ketiga: dinamika perubahan dan keruntuhannya (Harkantiningsih dkk, 2007 dan 2008).

Dan untuk melengkapi kajian-kajian tersebut diatas penulis menitiberatkan pada aspek mencari bukti arkeologis dan jejak orang Melayu sebagai penyebar agama Islam di wilayah Kerajaan GowaTallo. Sehingga dapat memberikan gambaran tentang kehadiran orang-orang Melayu yang datang menyebar agama Islam dan sekaligus berdagang karena tempat mereka berdagang di Malaka telah dikuasai oleh Portugis pada Tahun 1511 M.

Paska runtuhnya Malaka oleh Portugis pada Tahun 1511 M, para pedagang Melayu berangsur meninggalkan bandar Malaka dan mulai mencari pelabuhan lain untuk melanjutkan perdagangan secara aman, hingga sampai ke wilayah Kerajaan Gowa-Tallo. 1) Bagaimana bukti arkeologi orang Melayu sebagai penyebar agama Islam di wilayah bekas kerajaan Gowa-Tallo? 2) Bagaimana gambaran jejak-jejak awalul Islam di wilayah bekas Kerajaan Gowa-Tallo dalam perspektif arkeologi?

Tujuan Penelitian ini yakni untuk menemukan bukti arkeologis tentang keberadaan orang-orang Melayu di wilayah Kerajaan Gowa-Tallo dan untuk memberikan gambaran terkait awal penyebaran Islam di wilayah Kerajaan Gowa-Tallo oleh orang Melayu.

\section{Tinjauan Pustaka}

Pola penyebaran agama Islam di Nusantara selalu dibawa oleh orang luar, seperti kehadiaran orang Arab, Persia dan Gujarat di beberapa pelabuhan Asia Tenggara pada tahap awal 
memperkenalkan agama Islam pada penduduk setempat, fase perkenalan Islam diperkirakan berlangsung dari abad ke 9 sampai 13. Pada awal abad ke $13 \mathrm{M}$ di Barus sudah ada pemukiman masyarakat muslim, itu ditandai dengan adanya makam seorang wanita bernama Tuhar Amisuri, wafat pada 10 Safar 602 H/1203 M. Meski agama Islam baru melembaga pada akhir abad ke 13, hal itu bisa terlihat pada makam Malik Al-Saleh yang wafat pada bulan Ramadhan 696 H/1297 M, Malik Al-Saleh merupakan raja pertama di Kerajaan Pasai Aceh. Proses pelembagaan agama Islam terpusat di Kerajaan Pasai dan meluas ke Aceh, pesisir Sumatera, semenanjung Malaka, Demak, Gersik, Banjarmasin, Lombok, dan Islam terlambat melembaga di Sulawesi meski sebahagian penduduknya sudah menganut agama Islam (Ambary, 1998: 55-59).

Setelah penguasa Portugis di bawah pimpinan Alfonso de Albuquerque mendirikan benteng yang menandai penguasaannya di Malaka pada tahun $1511 \mathrm{M}$, pedagang-pedagang muslim berangsur meninggalkan bandar Malaka dan mulai mencari pelabuhan-pelabuhan lain untuk melanjutkan perdagangan secara aman. Perpindahan pedagangpedagang muslim ke daerah lain di Nusantara membuka peluang tersebarnya agama Islam ke seluruh daerah Nusantara dan kemunculan pelabuhan-pelabuhan baru menggantikan peran strategis Malaka sebagai pusat perdagangan internasional, antara lain di Sumatera dan Jawa (Poesponegoro dan Nugroho, 1993: 42).

Selain daerah yang telah disebutkan, kawasan timur Nusantara juga menjadi daerah tujuan para pedagang muslim, termasuk Makassar (Gowa-Tallo) yang pada masa itu sedang berupaya menjadi pusat perdagangan di kawasan timur Nusantara. Prinsip perdagangan bebas yang diterapkan kerajaan GowaTallo pada abad ke XVI sampai pertengahan XVII, telah membawah kemajuan dan kemakmuran, sehingga para pedagang dan pelaut yang berniaga ke Asia Tenggara dan Asia Timur telah menempatkan Makassar sebagai kota pelabuhan terpenting. Makassar menjadi pusat perdagangan komoditas dari Maluku, Papua, Kalimantan, Malaka, Sumatra, Jawa, Asia Selatan, Eropa, Filipina, Jepang, Cina, Nusa Tengara, dan Australia (Poelinggomang, 2002:6).

\section{METODE PENELITIAN}

Daerah penelitian yang menjadi objek meliputi bekas wilayah Kerajaan Gowa-Tallo yaitu
Kodya Makassar dan Kabupaten Gowa, penelitian ini berlangsung dari tahun 2013 dan 2014. Penelitian menggunakan metodologi kualitatif, yang melibatkan interpretasi atau penafsiran untuk memahami fakta sasaran penelitian (verstehen). Penelitian kualitatif sebagai medan penemuan pemahaman merupakan kegiatan yang tersusun atas sejumlah wawasan, disiplin, maupun wawasan filosofis sejalan dengan kompleksitas pokok permasalahan yang digarap (Maryaeni, 2005:3).

Metode pengumpulan data dengan dua cara yaitu, pertama : melakukan studi pustaka baik dari buku yang telah diterbitkan, jurnal, laporan hasil penelitian dan manuskrip naskah lontara. Kedua : melakukan observasi kelapangan dengan teknik survei dengan serangkaian kegiatan observasi, pengukuran, pencatatan, identifikasi, dokumentasi, dan mengambil sampel artefak. Kami juga melakukan ekskavasi uji test-pit untuk memperoleh gambaran lapisan budaya. Kami juga melakukan wawancara dengan pertanyaan terbuka kepada tokoh masyarakat kemudian memverifikasi pernyataan masyarakat dengan apa yang terterah di dalam naskah lontara. Data dianalisis dengan pendekatan induktif, deskriptif, dan tipologis. Penyajian data dalam bentuk foto, kutipan dokumen, dan pemaparan secara analitis fakta-fakta temuan, yang diikuti penjelasan dan konseptualisasi.

\section{PEMBAHASAN \\ Identifikasi Tinggalan Arkeologis}

Jejak orang-orang Melayu dalam penyebaran agama Islam di wilayah bekas Kerajaan GowaTallo dapat ditemukan tersebar di beberapa titik di Kabupaten Gowa dan Kotamadya Makassar yang merupakan teritori kekuasaan Kerajaan Gowa. Jejak-jejak tersebut dapat dilihat pada tinggalantinggalan masjid dan makam kuno seperti berikut:

\section{Masjid Mangallekana}

Masjid Mangallekana adalah masjid pertama yang dikenal dalam sejarah Sulawesi Selatan, yang menurut Noorduyn telah hancur menyusul penghancuran Benteng Somba Opu sebagai akibat kekalahan Gowa dalam Perang Makassar antara Sultan Hasanuddin dan VOC, begitu juga dengan lokasinya telah terkikis oleh Sungai Jeneberang (Sewang, 2005:84). Masjid Mangallekana berdiri pada abad XVI, dalam rentang masa pemerintahan Raja Gowa XI bernama Tonijallo (1565-1590), sebagaimana disebutkan di dalam lontara patturiolong ri tu Gowaya: 
iapa anne karaeng ampambangungangi masigi ri Mangallekana, nikellainna majannang mammempo ansuroi manai haji.

Terjemahan:

RajainilahmendirikanmasjiddiMangallekana bagi para pedagang, agar mereka mau tinggal menetap dan memberikan kemudahan dalam menunaikan ibadah haji.

Merujuk kepada informasi yang direkam dari lontara patturiolong ri tu Gowaya, lokasi Masjid Mangallekana diduga berada di sebelah selatan Benteng Somba Opu, tidak jauh dari pantai. Penelusuran wawancara menunjukkan dua titik yang diduga merupakan lokasi Masjid Mangalekana. Titik pertama berada di Barombong dan titik kedua berada di Taeng. Kedua titik lokasi berada di sebelah selatan Benteng Somba Opu. Merujuk kepada dugaan tersebut, maka dilakukan survei dan ekskavasi di kedua titik lokasi untuk menelusuri keberadaan masjid.

Tumpukan bata tidak beraturan ditemukan pada ekskavasi 1 x $1 \mathrm{~m}$ kedalaman $20 \mathrm{~cm}$ di dalam Kompleks Makam Tua di Barombong. Penduduk setempat menerangkan bata tersebut memanjang ke arah selatan dan bata yang sama banyak digunakan sebagai umpak tiang atau alas tangga rumah penduduk di selatan kompleks makam. Bata memiliki ketebalan 1,5 - $5 \mathrm{~cm}$, lebar 19 - 19,5 $\mathrm{cm}$, dan panjang 19,5 - $24 \mathrm{~cm}$. Pada kedalaman 88 $\mathrm{cm}$ ditemukan bata berhias dan fragmen keramik Cina dari era Dinasti Chings sekitar abad XVII M. Motif hias bata berbentuk bunga dan terdapat bekas tekanan jari tangan. Belum diperoleh kejelasan terkait dugaan struktur bata sebagai pondasi masjid

Gambar 1. Kiri: Kotak ekskavasi di Kompleks Makam Kuno di Barombong. Kanan: Bata berhias temuan ekskavasi (Dok. Balar Makassar, 2013).

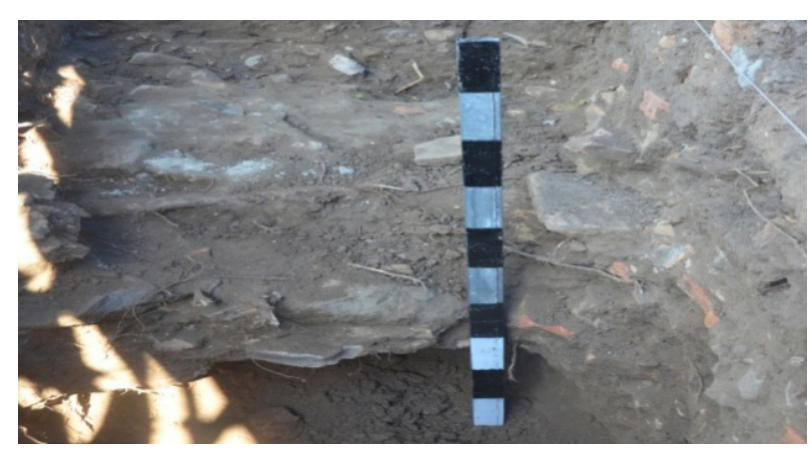

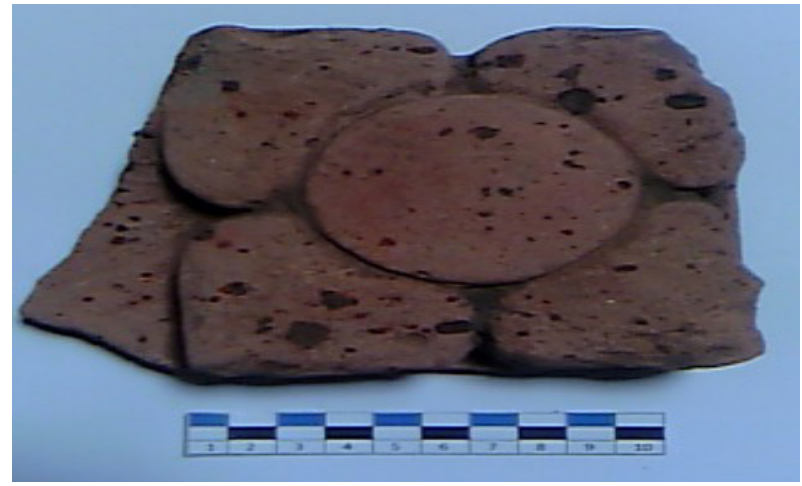

Adanya sumur tua di Taeng yang tersusun dari bata tanpa perekat seperti di Majapahit menjadi alasan dibukanya kotak ekskavasi 1 x $1 \mathrm{~m}$ di titik lokasi. Menurut H. Azis Puang Nangka (69 tahun), kawasan di sekitar sumur merupakan bekas surau atau langgar tempat masyarakat dulu melakukan pengajian dan peribadatan. Tidak jauh dari lokasi sumur, terdapat sungai yang dulunya adalah pelabuhan. Dalam naskah lontara tertulis, Taeng adalah tempat belajar hukum syariat Islam dahulu. Ekskavasi hingga kedalaman $50 \mathrm{~cm}$ menghasilkan jumpaan fragmen keramik asing dari Cina dan Eropa.

Gambar 2. Kiri: Kotak ekskavasi di Taeng. Kanan: Keramik Cina dan Eropa temuan ekskavasi

(Dok. Balar Makassar, 2013)
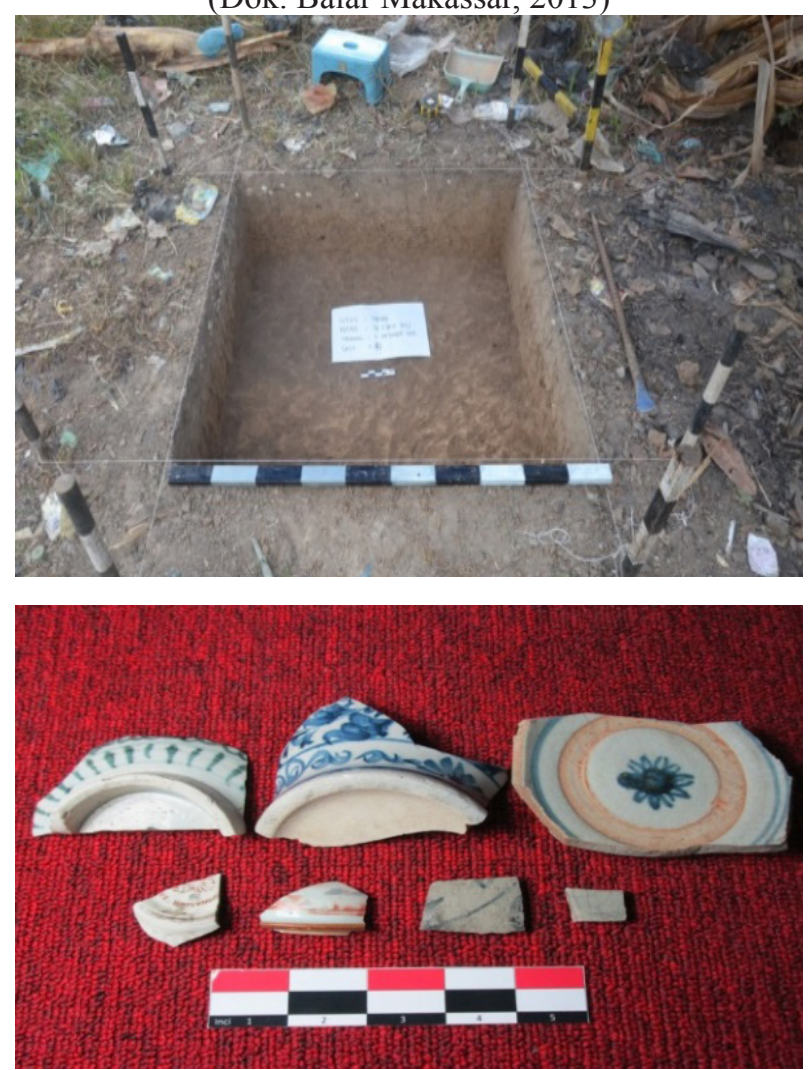


\section{Masjid Tua dan Kuburan Melayu}

Informasi mengenai keberadaan bekas Masjid

Tua Melayu diperoleh dari wawancara dengan Haji Ince Muhammad Unais Hasan, Imam Masjid Makmur Melayu. Bekas masjid tua terletak di Jalan Sangir, Kelurahan Melayu, Kecamatan Wajo, Kotamadya Makassar, di tengah pemukiman orangorang beretnis Tionghoa. Secara astronomis, bekas masjid berada pada titik koordinat $05^{\circ} 07^{\prime} 31.0^{\prime \prime}$ LS dan $119^{\circ} 25^{\prime} 16.4^{\prime \prime}$ BT.

Pada lahan dimana bekas Masjid Tua Melayu berada kini berdiri sebuah rumah panggung. Arsitektur rumah tipikal rumah tradisional BugisMakassar. Dindingnya terbuat dari gamacca atau anyaman bambu. Tiang-tiang rumah dari gelondongan kayu yang kondisinya telah lapuk. Menurut penduduk setempat, rumah tersebut telah lama tidak dihuni (kosong), sedangkan usianya diperkirakan lebih dari 50 tahun. Tanda-tanda keberadaan masjid terlihat pada adanya bekas lantai masjid, struktur batu-bata, dan bongkahan batu andesit di sekitar tangga rumah. Lantai menggunakan ubin jenis teraso berukuran $20 \mathrm{~cm} \mathrm{x}$ $20 \mathrm{~cm}$. Batu-bata pada struktur berukuran $25 \mathrm{~cm} \mathrm{x}$ $12 \mathrm{~cm}$ warna merah. Batu andesit berukuran $60 \mathrm{~cm}$ $\mathrm{x} 20 \mathrm{~cm}$.

Berjarak kurang $1 \mathrm{~km}$ dari Masjid Tua Melayu terdapat Makam Datuk Imam Balla' Jati, yaitu pada titik koordinat $05^{\circ} 07^{\prime} 30.8^{\prime \prime} \mathrm{LS}$ dan $119^{\circ} 24^{\prime} 40.3^{\prime \prime}$ BT. Menurut Haji Ince Muhammad Unais Hasan, pada mulanya terdapat banyak makam di lokasi makam yang juga dikenal dengan sebutan "Kuburan Melayu", namun kini hanya tersisa sebuah makam yang diduga milik Datuk Imam Balla' Jati, orang Melayu yang pernah menjadi imam di Masjid Tua Melayu.

Gambar 3. Makam Datu' Imam Balla' Jati di Jl. Sangir, Kel. Melayu, Kec. Wajo, Kota Makassar

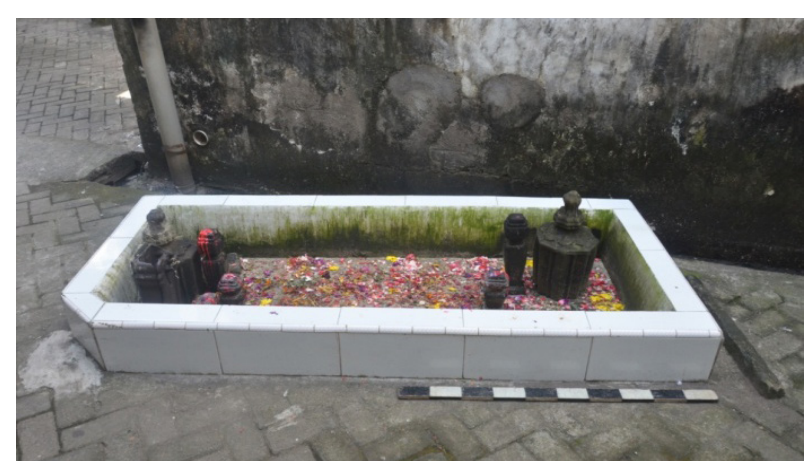

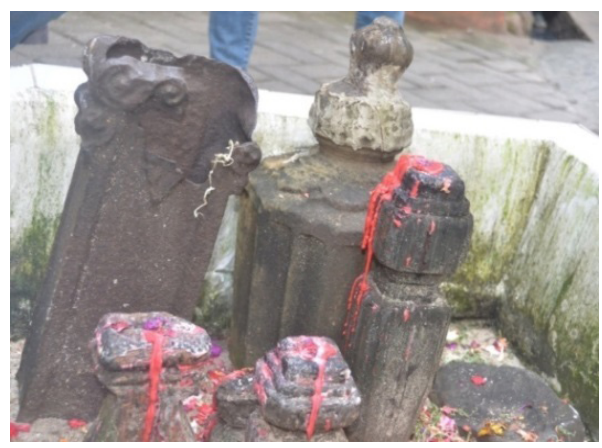

Makam berorientasi utara-selatan. Hanya nisan yang teridentifikasi memiliki ciri kekunoan, yaitu terdiri dari nisan bertipe Aceh dan pipih. Nisan tipe Aceh terbuat dari batu andesit, berukuran tinggi $48 \mathrm{~cm}$ dan diameter $22 \mathrm{~cm}$, berbentuk dasar persegi delapan. Pada bagian kepala/leher nisan terdapat motif hias timbul berbentuk menyerupai bunga teratai (lotus) berkelopak delapan. Badan semakin ke atas semakin membesar, kemudian mengecil dari leher hingga kepala. Nisan tipe pipih terbuat dari logam besi, berukuran tinggi $40 \mathrm{~cm}$ dan lebar $14 \mathrm{~cm}$. Kondisi nisan tidak lagi utuh (terpotong) dan berkarat. Nisan hanya terdapat di bagian kepala nisan dan tidak tertanam di dalam tanah makam. Diduga, nisan berasal dari makam lain yang telah dihilangkan.

\section{Masjid Makmur Melayu}

Masjid Makmur Melayu berada di Kelurahan Melayu Baru, Kecamatan Wajo, Kotamadya Makassar. Secara astronomis terletak pada titik koordinat $05^{\circ} 07^{\prime} 32.0^{\prime \prime}$ LS dan $119^{\circ} 24^{\prime} 34.3^{\prime \prime}$ BT. Bangunan berdiri di tengah-tengah Rumah Toko (Ruko) warga etnis Tionghoa, di dalam lingkungan Pecinan (China Town) Kota Makassar, persis di tepi jalan persimpangan (sudut) jalan Sulawesi dan Jalan Sangir, di atas lahan seluas 15 m x 19 m. Sebelum pelebaran jalan dan pemotongan sebagian bangunan, luas lahan $21 \mathrm{~m}$ x $20 \mathrm{~m}$.

Menurut Haji Ince Muhammad Unais Hasan (70 tahun), imam Masjid Makmur Melayu yang masih keturunan Datuk ri Bandang, masjid dibangun pada abad XVIII, yaitu sekitar tahun 1760 M. Nama Masjid Makmur Melayu adalah bentuk penghormatan terhadap jasa-jasa Datuk ri Bandang (Khatib Tunggal Datuk Makmur). Penunjukan lokasi pembangunan masjid melibatkan jasa seorang Melayu Pegawai Belanda bernama Ince 
Ali Abdullah atau Datuk Pabean. Pada awal pendiriannya, masjid hanya berlantai satu dan masih menggunakan bahan kayu. Tahun 1943 saat perang dunia II, masjid dihantam bom sehingga hancur dan rata dengan tanah. Dengan demikian, bangunan yang ada sekarang, tidak lagi orisinil seperti awal pendiriannya.

Pasca pengeboman, masyarakat Kampung Melayu membangun kembali Masjid di bawah koordinasi Haji Ince Muhammad Hasan (ayah Unais Hasan). Ketika itu, masjid masih tetap dibuat berlantai satu, dinding masjid menggunakan gamacca, yaitu anyaman kulit pelepah daun nipah atau rumbia. Pada tahun 1948, konstruksi dinding diganti tembok, tersusun dari tiga lapisan batubata merah. Kemudian tahun 1982, masjid dipugar, dibuat berlantai dua seperti yang terlihat kini.

\section{Masjid An-Nur}

Masjid kuno An-Nur terletak di Kampung Melayu Makassar. Bentuk masjid yang dijumpai sekarang bukan lagi bentuk aslinya. Masjid kini dipelihara oleh Sayyid Ahmad Qamaruddin Assaggaf (78 tahun).

\section{Masjid Kaluku Bodoa}

Masjid Kalukubodoa terletak di Kelurahan Kalukubodoa, Kecamatan Tallo, Kota Makassar. Masjid Kalukubodoa telah direnovasi oleh penduduk setempat sehingga menghilangkan bentuk aslinya, kecuali sumur yang masih asli, yang hingga kini masih dimanfaatkan oleh jemaah.

\section{Masjid Sayyid Jalaluddin Al-Aidid}

Masjid Sayyid Jalaluddin Al-Aidid kini hanya menyisakan sebuah struktur sumur berdiameter $70 \mathrm{~cm}$, struktur atau susunan batu-batu andesit dan bata yang diduga merupakan pondasi masjid. Secara astronomis, bekas masjid tua terletak di titik koordinat $05^{\circ} 32^{\prime} 06.8^{\prime \prime} \mathrm{LS}$ dan $119^{\circ} 26^{\prime} 24,4^{\prime \prime}$ ' BT, pada ketinggian $43 \mathrm{~m}$ dari permukaan laut (mdpl). Situs berada di dalam lingkungan Kecamatan Bajeng, Kabupaten Gowa, Provinsi Sulawesi Selatan, $647 \mathrm{~m}$ arah barat laut. Struktur sumur dan pondasi masjid diyakini oleh masyarakat setempat sebagai bekas bangunan masjid yang didirikan oleh Sayyid Jalaluddin Al-Aidid.
Gambar 4. Struktur sumur dan bekas pondasi Masjid Tua Cikoang (Dok. Balar Makassar, 2014).

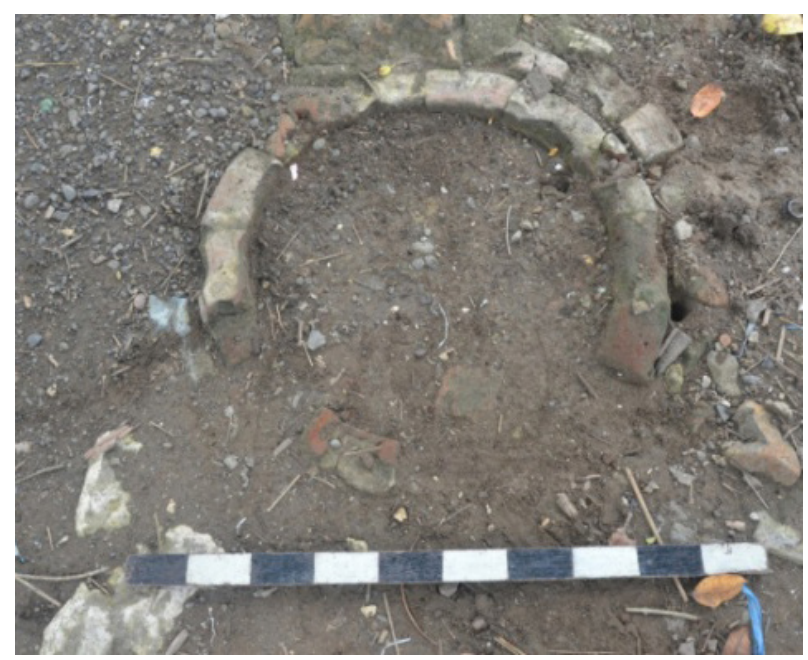

Sayyid Jalaluddin al-Aidid adalah tokoh yang terkait dengan asal usul komunitas Islam Sayyid di Cikoang, Kabupaten Takalar dan sesepuh keturunan fam al-Aidid di Nusantara (Anonim, 2009). Kedatangannya yaitu pada akhir abad XVI M sebelum Raja Gowa-Tallo menerima Islam. Pengikut Sayyid Jalaluddin melakukan perjalanan ke Buton, Selayar, dan terakhir ke Sumbawa, dimana Sayyid Jalaluddin wafat dan dimakamkan (Hamonic, 1985). Sampai sekarang komunitas Islam Sayyid dapat dijumpai di wilayah Kecamatan MangaraBombang, Kabupaten Takalar. Selain itu, beberapa kitab yang diyakini oleh masyarakat sebagai kitab pedoman Sayyid Jalaluddin dalam melakukan pengajaran masih tersimpan dan digunakan oleh masyarakat setempat.

Gambar 5. Kitab Sayyib Jalaluddin di Cikoang, Kab. Takalar (Dok. Balar Makassar, 2014)

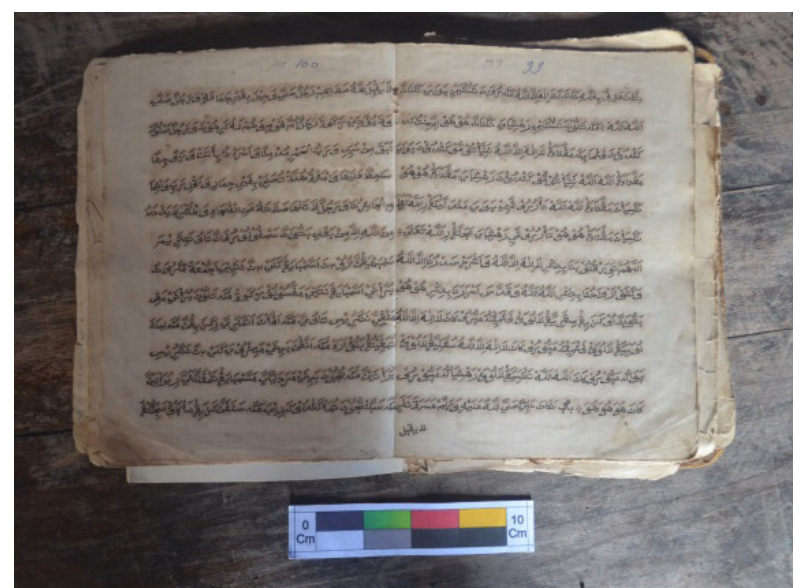




\section{Kompleks Makam Lajangiru Bontoala}

Kompleks makam terletak tepat di tepi Jalan Kandea 7, Desa/Kelurahan Bontoala Tua, Kecamatan Bontoala, Kotamadya Makassar, Provinsi Sulawesi Selatan. Secara astronomis, situs berada pada titik koordinat $05^{\circ} 07^{\prime} 42.4^{\prime \prime}$ LS dan $119^{\circ} 25^{\prime} 16.4^{\prime \prime}$ BT. Luas areal makam yaitu $629,86 \mathrm{~m}^{2}$. Makam berjumlah 233 buah, dengan empat buah cungkup (kobbang) berbentuk menyerupai masjid kubah. Setiap cungkup berisi 2-4 buah makam. Nama-nama yang dimakamkan di dalamnya diidentifikasi sebagai orang Melayu, diantaranya Ince Habib Hasan (wafat 1920 M), Habib Muhsin, Habib Assegaf, Habib Ali Sihab, dan Habib Adam Muri.

Gambar 6. Tipe-tipe cungkup di Kompleks Makam Lajangiru Bontoala. Kiri: Cungkup berkubah limas segi empat; Kanan: Cungkup berkubah oval bawang (Dok.

Balar Makassar, 2014).

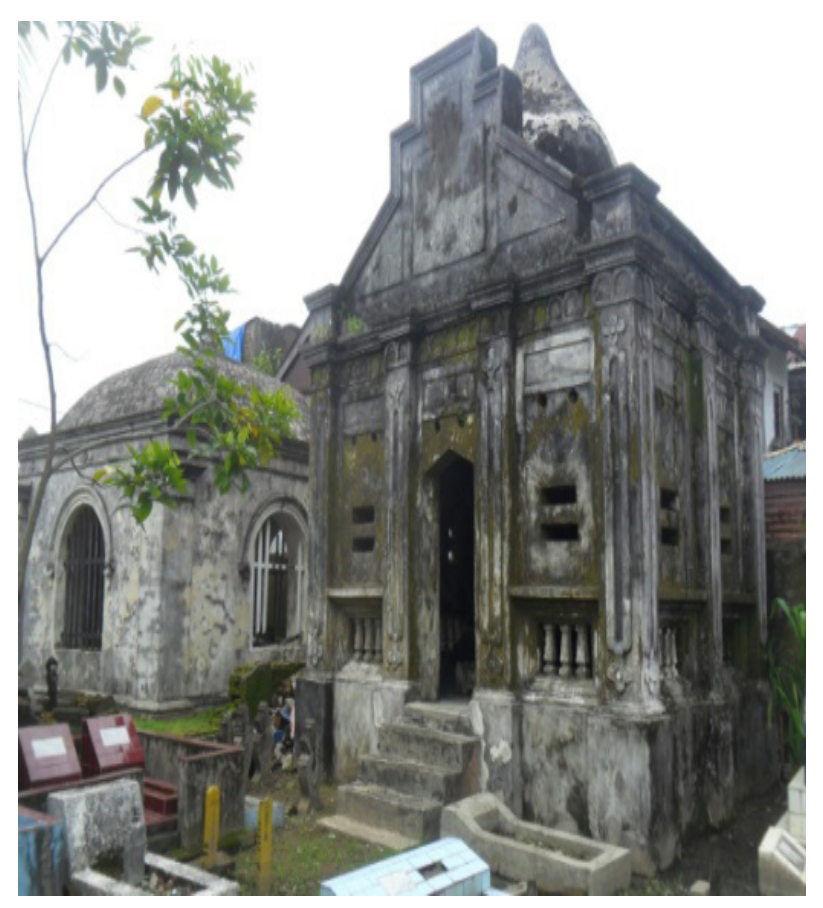

Cungkup makam di Kompleks Makam Lajangiru Bontoala terbuat dari bahan konstruksi batu dengan campuran semen dan pasir. Ruang tengah berbentuk segi empat. Bentuk kubah cungkup terdiri dari limas segi empat dan oval bawang. Cungkup berkubah limas segi empat tidak memiliki banyak hiasan, kecuali pelipit dan pelengkung semicircular di atas pintu, serta empat buah pilaster di sudut dinding barat. Pintu dan jendela cungkup berkubah limas segi empat berbentuk tapal kuda. Cungkup berkubah oval bawang memiliki stepped gable, pintu berbentuk segi lima, dan ventilasi berupa lubang-lubang bulat kecil dan persegi panjang serta kisi-kisi beton. Di sekeliling dinding terdapat pilaster berhias dua bunga berkelopak empat di bagian base dan capital. Bagian teratas dan terbawah dinding cungkup dihiasi pelipit.

Makam-makam di dalam cungkup Jirat makam umumnya bertipe teras bertingkat dua dan memiliki gunungan. Bahan jirat semen campur bata ditehel dan tidak, nisan terdiri dari tipe pedang, silindrik, blok. Gunungan dan nisan makam bahan marmer, batu granit. Gunungan dan dinding jirat memiliki inskripsi dan hiasan ukiran sulur-sulur bunga. Nisan bahan kayu ada hiasan inskripsi arab dan lontara. Makam di luar cungkup jirat blok batu, dan peti batu. bahan batu andesit, bata lapis semen atau tegel. Nisan tipe pipih dan silindrik dari bahan batu andesit dan kayu.

Gambar 7. Tipologi nisan di Kompleks Makam Lajangiru Bontoala (Dok. Balar Makassar, 2014)

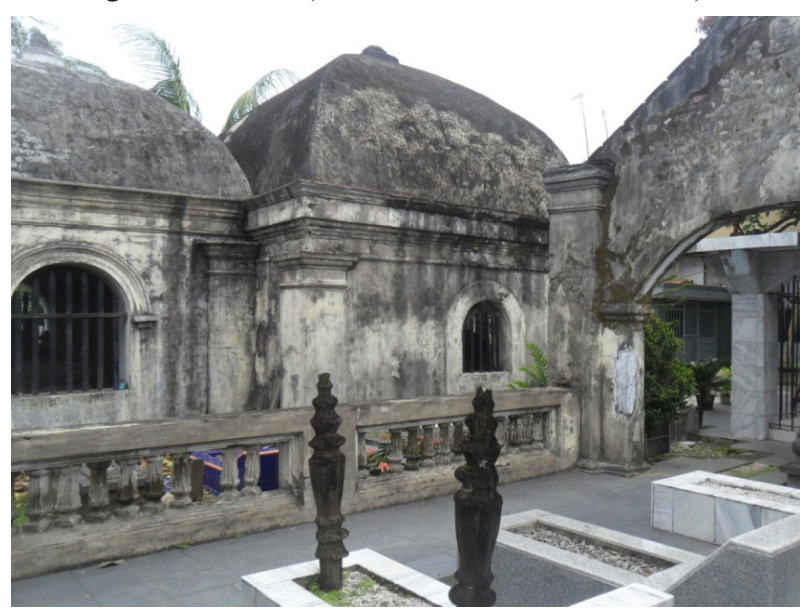

\section{Datuk Ribandang}

Makam Datuk ri Bandang terletak di Jalan Sinassara, Kelurahan Kalukubodoa, Kecamatan Tallo, kurang lebih $6 \mathrm{Km}$ sebelah utara pusat Kota Makassar atau Lapangan Karebosi. Lokasi situs dapat diakses dengan kendaraan umum atau mobil pribadi. Secara astronomis, situs terletak pada titik koordinat $05^{\circ} 06^{\prime} 59.4^{\prime \prime}$ LS dan $119^{\circ} 26^{\prime} 13.8^{\prime \prime}$ BT. Luas area $377,03 \mathrm{~m}^{2}$.

Makam Datuk ri Bandang diletakkan di dalam sebuah bangunan menyerupai rumah batu berukuran luas $15,52 \mathrm{~m}^{2}$ berorientasi ke utara. Atap bangunan berbentuk limasan (joglo) dengan denah persegi. Konstruksi dinding batu-bata, bercat hijau muda. Lantai ruangan dalam ditutupi semen. Pintu berbentuk tapal kuda, daun berbahan panil kayu warna hijau tua. Terdapat ventilasi berupa lubanglubang berbentuk persegi panjang kecil di sekeliling 
dinding bagian atas. Di depan bangunan terdapat teras, lantai ditutupi tegel putih. Makam Datuk ri Bandang terbuat dari bahan batu granit, berorientasi utara-selatan. Struktur makam terdiri dari jirat, gunungan, dan nisan. Makam memiliki kelambu. Rangka kelambu terbuat dari kayu yang dicat warna hijau tua. Kain kelambu berwarna merah jambu cenderung putih. Jirat makam jirat tipe peti batu berbentuk persegi panjang. Jirat berukuran panjang $276 \mathrm{~cm}$, lebar $168 \mathrm{~cm}$, tebal $45 \mathrm{~cm}$ dan tinggi dari dasar lantai $46 \mathrm{~cm}$. Gunungan berjumlah dua buah, terletak di kepala (utara) dan kaki makam (selatan), berukuran tinggi $39 \mathrm{~cm}$. Nisan berjumlah satu buah, terletak di kepala (utara), terbuat dari batu berwarna hitam. Nisan berukuran tinggi $66 \mathrm{~cm}$ dan lebar $17 \mathrm{~cm}$. Nisan bertipe Aceh. Bentuk dasar nisan ialah persegi dengan tiga ukiran berbentuk persegi panjang pada badan nisan dan kepala bersusun dua.

Gambar 8. Makam Datuk ri Bandang di Jl. Sinassara, Kel. Kalukubodoa, Kec. Tallo, Kota Makassar (Dok. Balar Makassar, 2014)
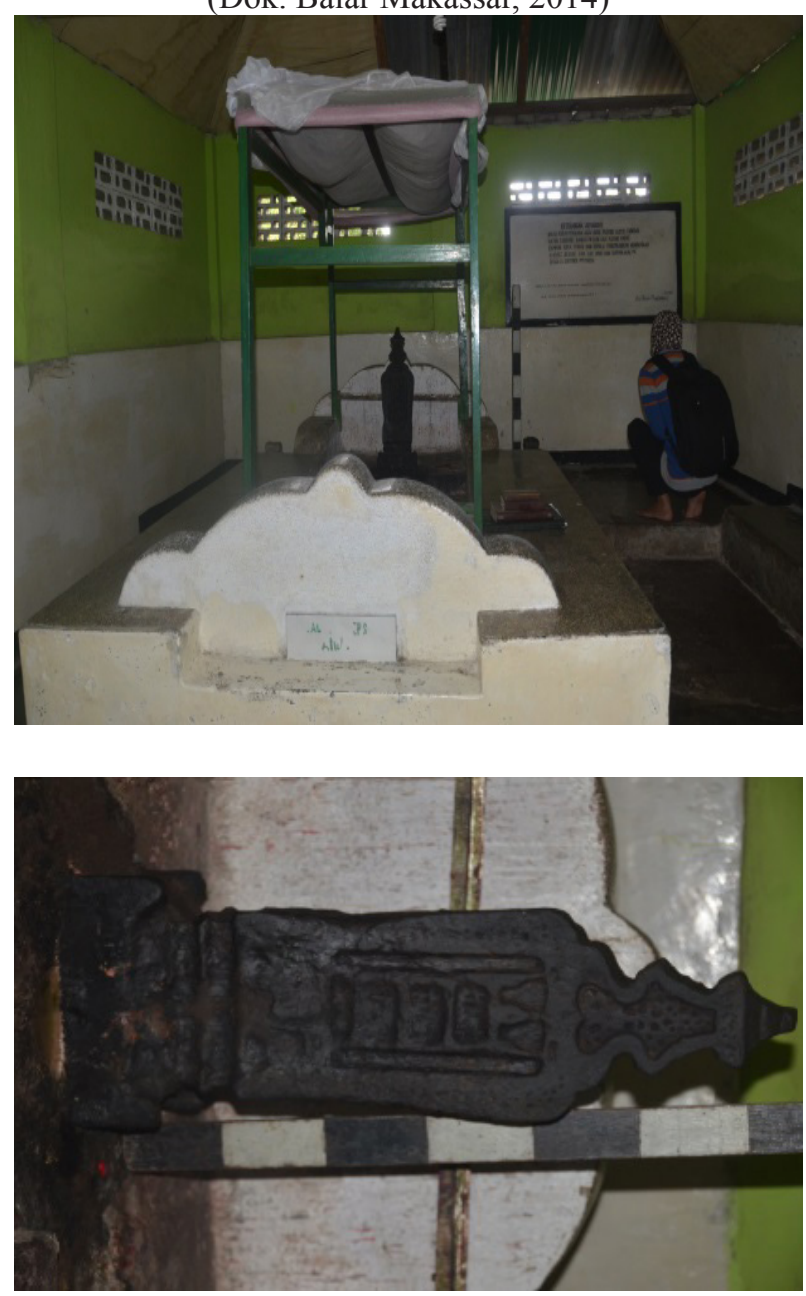

\section{Jejak Awalul Islam di Kerajaan Gowa-Tallo dalam Perspektif Arkeologi}

Kehadiran orang Melayu untuk menyebarkan agama Islam di Kerajaan Gowa pada awal abad XVI dapat dilacak di dalam lontara Gowa yang mencatat bahwa, pada tahun $1574 \mathrm{M}$ di Kerajaan Gowa telah datang seorang dari Melayu, pada teks lain menyebut seorang dari Jawa bernama I Galasi. Boleh jadi nama I Galasi adalah peristilahan lokal Makassar yang kemungkinan besar diambil dari kata kelasi, sebuah kata yang berkaitan erat dengan perahu, yang bisa diartikan, "orang yang datang dengan perahu". Menurut Noorduyn, I Galasi adalah seorang kelasi dari Tanah Melayu. I Galasi datang bertepatan pada masa pemerintahan Raja Gowa IX bernama Karaeng Tumaparrisi Kallonna (wafat tahun 1547). Meskipun tidak dicatatkan secara rinci mengenai apa yang dilakukan oleh I Galasi, namun namanya merupakan bukti kehadiran orang Melayu di Sulawesi Selatan pada awal abad XVI.

Ricklefs (2008: 76) mengatakan bahwa, Sunan Bonang pernah mengunjungi Makassar dalam rangka penyebaran agama Islam. Ricklefs berkesimpulan, Sunan Bonang memainkan peranan yang sangat penting dalam mengenalkan agama Islam ke Lombok, Makassar, Kutai (Kalimantan Timur), dan Pasir (Kalimantan Tenggara). Naskah lontara pattoriolonga ri to Gowaya menyebutkan (Sewang, 2005: 83-84), pada masa pemerintahan Raja Gowa X bernama Tonipalangga I Manriogau Daeng Bonto Karaeng Lakiung, telah datang seorang utusan orang-orang Melayu, Datuk Anakkoda Bonang, menghadap kepadanya agar diberi hak atas sebuah kawasan perkampungan di Makassar, seperti dikisahkan berikut:

Iatommi napappalakki empoang Jawa nikanaya Anakoda Bonang. Naia erang-erangna ri Karaenga, nappalaina empoang, kontua anne: kamaleti sibatu, belo sagantuju pulona sowonganna, sakalla' sikayu, bilu'lu sikayu, cinde ilau sitangga kodi. Nakana Anakoda Bonang ri Karaenga Tonipalangga; "appaki rupana kupala-palaka rikatte karaeng; "nakanamo karaenga: "apa?" Nakanamo: "kipalaki, tanipantamaia embammang, tanigayanga punna nia'anammang, tani rappung punna nia' salamang." Naniioi ri Karaenga; nakana karaenga: tedongkujanjo maposo nakuparamme, mabattala'nakutaroi, alaikaupaseng parangku tau, naiajia tamammunoako ributtaku punna kuasenga. Nanakanatodong, "Siapai rupanna nupailalang kana-kana?" Nakanamo Anakkoda Bonang, "Sikontukang Ikambe ma'lipa" 
baraya kontui Pahangan, Patania, Campaya, Marangkaboa, Johoroka."

Artinya; Dialah yang meminta (memberi) tempat kediaman pada orang Jawa yang disebut Anakkoda Bonang. Adapun persembahannya kepada raja ketika ia meminta tempat kediaman, ialah: sepucuk kamelati, delapan puluh junjungan "belo", sekayu sekelat, sekayu beludu dan setengah kodi cinde iali. Kata anakoda bonang kepada raja tonipalangga: "empat macam kami harapharapkan dari tuanku; "maka menyahutlah Raja itu "apa itu?" Ia menjawab; "kami minta supaya jangan dimasuki pekarangan kami (dengan begitu saja), janganlah kami dikenakan peraturan "nigayang" bila ada anak kami, dan janganlah kami dikenakan peraturan "nirappung" bila ada kesalahan kami. Maka diperkenankanlah (permintaan itu) oleh Raja, "Sedangkan kerbauku bila lelah kuturunkan ke dalam air, bila bebannya berat saya turunkan sebagian, apalagi engkau sesamaku manusia, akan tetapi janganlah engkau melakukan pembunuhan dalam kerajaanku di luar pengetahuanku. Berkatalah pula Raja, "Berapa macam (orang) yang kau masukkan ke dalam permintaan itu?" Berkatalah Anakkoda Bonang, "semua kami yang bersarung ikat ialah (orang) Pahang, Patani, Campa, Minangkabau, dan Johor”.

Orang-orang Melayu kemudian diberikan hak menetap di sekitar Pelabuhan Somba Opu, yaitu Kampung Mangalekana (Sewang, 2005: 85), juga diperbolehkan menikahi putera dan puteri Kerajaan Gowa (Zuhri, 1979: 429).

Boleh jadi orang Jawa yang dimaksud dalam naskah lontara adalah Sunan Bonang yang oleh pelafalan orang Makassar menjadi Anakkoda Bonang. Bilamana disebutkan ia adalah utusan orang Melayu, hal ini bisa dikaitkan dengan Syaikh Maulana Ishak, guru Sunan Bonang di Malaka. Naskah carita Lasem mencatat Sunan Bonang (Bong Ang) sebagai cucu putri Champa bernama Bi Nang Ti, anak dari Sunan Ampel (Bong Swi Ho). Sunan Bonang diketahui salah satu wali sembilan di Pulau Jawa. Pada awal abad XVI beberapa Kerajaan di Nusantara diislamkan oleh Jawa, namun rupanya upaya pengislaman di Kerajaan Gowa tidak berhasil (Soekmono, 2006: 48). Meskipun demikian, tidak menutup kemungkinan bahwa Islam telah diterima secara perorangan oleh penduduk Makassar, baik pada tingkatan rahasia maupun pada tingkatan pribadi (Sewang, 2005:
79-80). Menurut lontara sukkukna ri Wajo, selain untuk berdagang, kedatangan Anakkoda Bonang juga untuk menyebarkan agama Islam. Namun, upaya Anakkoda Bonang dalam syiar Islam tidak berjalan baik karena ia kurang memahami budaya masyarakat di dalam wilayah Kerajaan Gowa-Tallo Makassar (A. Zainal AF, 1999: 228-229).

Selain didorong oleh keinginan berdagang dan menyebarkan agama Islam, kedatangan orang Melayu di Kerajaan Gowa-Tallo didorong oleh kristinisasi penguasa Siang yang menyebabkan pedagang-pedagang Melayu muslim di Siang berpindah dan adanya jaminan kebebasan bagi pedagang Melayu untuk menetap di Makassar karena pengalamannya dalam perdagangan internasional yang akan menguntungkan bagi pemasukan pajak kerajaan Gowa-Tallo (Andaya, 2004: 34). Sejak awal kedatangannya, orang Melayu tidak hanya berperan di dalam perdagangan dan penyebaran agama Islam, tetapi juga dalam bidang sosial budaya dan birokrasi. Tersebut nama I Daeng ri Mangallekana yang diangkat sebagai syahbandar kedua di masa pemerintahan Raja Gowa X, hingga Ince Husain sebagai syahbandar terakhir. Dikenal pula Ince Amin, juru tulis istana terakhir pada masa pemerintahan Sultan Hasanuddin, penulis syair Perang Makassar (Sewang, 2005: 85). Keturunan orang Melayu masih dapat dijumpai hingga kini dan dikenali dengan sebutan Enci atau Ince. Karena besarnya peranan orang Melayu itu, maka pada tahun 1580 M, Raja Gowa XI yang bernama Tunijallo (1565-1590 M) mendirikan sebuah masjid untuk orang Melayu di Kampung Mangallekana, dekat istana Kerajaan Gowa, Somba Opu, meskipun Islam belum diterima sebagai agama kerajaan (Pelras, 2010:102), seperti disebutkan dalam lontara patturiolong ri tu Gowaya:

\section{iapa anne karaeng ampambangungangi masigi ri Mangallekana, nikellainna majannang mammempo ansuroi manai haji.}

Terjemahan:

RajainilahmendirikanmasjiddiMangallekana bagi para pedagang, agar mereka mau tinggal menetap dan memberikan kemudahan dalam menunaikan ibadah haji.

Masjid Mangallekana adalah masjid pertama yang dikenal dalam sejarah Sulawesi Selatan, yang menurut Noorduyn telah hancur menyusul penghancuran Benteng Somba Opu sebagai akibat kekalahan Gowa dalam Perang Makassar antara Sultan Hasanuddin dan VOC, begitu juga dengan 
lokasinya telah terkikis oleh Sungai Jeneberang (Sewang, 2005: 84). Meskipun demikian, penemuan struktur bata di Barombong dan sumur tua di Taeng diestimasi sebagai dua titik lokasi berdirinya Masjid Mangallekana. Dugaan yang lebih kuat nampaknya mengarah ke Taeng, jika merujuk kepada informasi yang ada, bahwa kawasan di sekitar sumur merupakan bekas surau atau langgar tempat masyarakat dulu melakukan pengajian dan peribadatan. Ditambah dengan catatan dalam lontara, Taeng adalah tempat belajar hukum syariat Islam dahulu. Identifikasi temuan keramik asing di Taeng dan Barombong, menghasilkan perkiraan usia relatif abad XVII M, lebih muda dibanding masa pendirian Masjid Mangallekana. Terkait dugaan Taeng sebagai lokasi toponimi Kampung Mangallekana kini tentunya masih membutuhkan penelitian lebih mendalam, dan masih terlalu dini untuk mengesahkan temuan sebagai bagian dari Masjid Mangallekana.

Kegagalan Anakkoda Bonang dalam upaya penyebaran Islam di Kerajaan Gowa mendorong Raja Aceh, Sultan Iskandar Muda Darma Wangsa Perkasa Alam Syah mengutus tiga mubalig dari Koto Tengah, Minangkabau, untuk mengislamkan elit Kerajaan Gowa-Tallo (Rosmawati, 2013: 74). Ketiga datuk tersebut yaitu, Datuk ri Bandang (Abdul Makmur Khatib Tunggal), Datuk ri Pattimang (Khatib Sulaeman), dan Datuk ri Tiro (Khatib Bungsu). Malam Jumat tanggal 22 September 1605 M (9 Jumadil Awal 1014 H), Datuk ri Bandang mengislamkan Raja Tallo bernama I Malingkanang Daeng Nyonri Karaeng Tumenanga ri Bonto Biraeng diberi gelaran Islam Sultan Abdullah Awwalul Islam, disusul Raja Gowa XIV bernama I Manga'rangi Daeng Manrabia yang diberi gelaran Islam Sultan Alauddin. Rakyat Kerajaan Makassar dinyatakan memeluk agama Islam dua tahun kemudian, yang ditandai dengan sholat Jumat pertama di Tallo pada tanggal 9 November 1607 M (10 Rajab 1016 H). Sejak saat itu, Kerajaan Makassar resmi menjadi kerajaan Islam (Sewang, 2005: 2).

Sumber yang ditulis oleh Sultan Aceh dan Sultan Johor menyebutkan bahwa, untuk mengembangkan dan menyiarkan agama Islam di Sulawesi-Selatan, mereka terlebih dahulu mempelajari kebudayaan orang Bugis-Makassar, di Riau dan Johor, dimana banyak orang-orang Bugis-Makassar berdiam. Setelah tiba di Makassar, mereka memperoleh keterangan dari orang Melayu di Gowa, bahwa raja yang paling dimuliakan dan dihormati adalah Datuk Luwu, dan yang paling kuat dan berpengaruh ialah Raja Gowa dan Tallo (A.
Zainal AF, 1990: 228-231). Datuk ri Bandang sendiri, menurut Graaf dan Pigeaud sebelum ke Makassar terlebih dahulu belajar di Giri. Ketiga datuk setibanya di Makassar tidak langsung melaksanakan misinya, tetapi terlebih dahulu menyusun strategi dakwah (Sewang, 2007). Datuk ri Bandang berhasil mengislamkan raja Gowa, sehingga rakyat kemudian mengikuti rajanya. Dalam hal ini, Datuk ri Bandang telah memanfaatkan dengan baik kharisma, kewibawaan, wewenang, dan kekuasaan raja (Noorduyn, 1964:87).

Datuk Ri Bandang disebutkan mendirikan sebuah masjid di Kalukubodoa, yang sayangnya tidak dapat dilacak dimensi kronologisnya. Masjid tersebut benar ada, namun tidak dapat lagi diamati bentuk originalnya. Masjid menjadi pusat pengajian Islam yang banyak dikunjungi oleh murid-murid dari dalam negeri Gowa, serta dari segenap negerinegeri Bugis dan Makassar yang telah menerima agama Islam. Pengajian dan pengajaran agama Islam di Kalukubodoa berkonsentrasi pada aspek fiqih. Sebelum agama Islam diterima di Kerajaan Makassar, Datuk ri Bandang mendirikan sebuah pesantren sebagai pusat syiar Islam pertama. Letak pesantren tersebut di sebelah utara Benteng Ujung Pandang, tepatnya di lahan dimana Masjid Makmur Melayu berdiri sekarang. Menurut catatan lontara lakatoanna Bontoala, setelah agama Islam resmi diterima sebagai agama kerajaan, daerah Bontoala menjadi pusat pengembangan Islam pertama. Sayyid Ba'Alwy bersama-sama dengan Datuk ri Bandang melakukan pendidikan dan pengajaran Islam di tempat tersebut. Nama-nama ulama yang lahir dari pendidikan di Bontoala antara lain, Syekh Yusuf AlMakassari, Lo'mo ri Antang, Datuk Pagentungan, Karaeng ri Tasammeng, dan Sayyid Muhyidin Aba Maksum Tajul Qubadi dari Bima.

Datuk ri Bandang dimakamkan di Kalukubodoa. Identifikasi arkeologis pada makamnya telah menemukan makam dengan jirat bertipe peti batu berbahan batu granit dan nisan tipe Aceh berbahan batu alam dengan sebuah gunungan. Makam dengan tipe demikian merupakan tipe makam yang umum digunakan oleh masyarakat Melayu pada abad XVI hingga abad XVII M. Penggunaan nisan tipe Aceh menandakan pemiliknya memiliki kemampuan ekonomi yang baik (Rosmawati, 2013: 480). Makam lain yang dijumpai di Kelurahan Wajo, makam Datuk Imam Balla' Jati (Kuburan Melayu), memiliki nisan tipe Aceh berbahan batu andesit juga berkembang pada masa yang sama dengan makam Datuk ri Bandang, demikian pula makam-makam bercungkup 
di Kompleks Makam Lajangiru Bontoala yang memiliki nisan tipe pedang dan blok. Nisan makam di Kelurahan Wajo memiliki ornamen lotus (teratai) berkelopak delapan. Lotus yang menghiasi nisan bukanlah menunjukkan ciri Islam, namun identik dengan Buddha, yang menunjukkan adanya akulturasi antara budaya Melayu (Islam) dengan Buddha (Cina).

Pasca perang antara VOC dengan Kerajaan Gowa yang berlangsung antara tanggal 21 Desember 1666 hingga 18 November 1667, orang-orang Melayu yang merasa terganggu oleh kehadiran orang-orang Bugis meminta kepada Belanda untuk dipindahkan dan diberi tempat di daerah Hutan Bulakeng yang kemudian disebut Kampung Melayu di sebelah utara Benteng Ujung Pandang. Atas perintah pemerintah Belanda, orang-orang Melayu menunjuk seorang pemimpin bergelar Kapiten Melayu untuk memimpin mereka (Mattulada, 1991).

\section{PENUTUP}

Jejak penyebaran agama Islam oleh orang Melayu di teritori Kerajaan Gowa-Tallo yang terekam di dalam naskah lontara sukkukna ri Wajo dan naskah lontara patturiolong ri tu Gowaya, dapat dibuktikan dengan adanya peninggalan masjid dan makam kuno di beberapa tempat di Kabupaten Gowa dan Kota Makassar. Jika melihat persebaran temuan, maka dapat diketahui bahwa, orang-orang Melayu mengokupasi daerah Kelurahan Melayu, Kecamatan Wajo di sebelah utara Benteng Ujung Pandang (Fort Rotterdam); Kelurahan Kalukubodoa, Kecamatan Tallo; Desa Bontoala Tua, Kecamatan Bontoala di Kota Makassar; dan beberapa daerah di Kabupaten Gowa diantaranya, Barombong dan Taeng.

Merujuk kepada catatan lontara dan peninggalan arkeologis, setidaknya terdapat dua fase permukiman orang Melayu, yaitu fase pertama: pada awal kedatangannya, yaitu pada periode pemerintahan Raja Gowa X dan Raja Gowa XI di awal abad XVI, orang-orang Melayu bermukim di Kampung Mangallekana, sebuah wilayah di dekat Pelabuhan Somba Opu; dan fase kedua: pada pertengahan abad XVII, yaitu pasca Kerajaan Gowa digempur oleh VOC, orang-orang Melayu dipindahkan ke Kampung Melayu di utara Benteng Ujung Pandang. Sangat disayangkan bahwa peninggalan arkeologis yang dapat dijumpai dari permukiman orang Melayu pada fase pertama terkait dengan proses Islamisasi di Kerajaan Makassar, hanyalah Masjid Mangallekana. Hasil ekskavasi di Taeng yang diduga sebagai lokasi toponimi Kampung Mangallekana tempat Masjid Mangallekana berada masih menyisakan banyak tanda tanya, sehingga membutuhkan penelitian lanjutan dan lebih mendalam di masa akan datang.

Fase Islamisasi Kerajaan Makassar yaitu, fase pertama: awal kedatangan orang Melayu pada awal abad XVI M, Islamisasi Kerajaan Makassar dilakukan oleh Anakkoda Bonang (Sunan Bonang), yang sayangnya tidak berjalan baik atau gagal, dalam artian Raja Gowa belum berhasil diislamkan. Walau demikian, terdapat kemungkinan, telah ada penduduk (perorangan) Makassar dalam tingkatan rahasia maupun pribadi menerima agama Islam; fase kedua: awal abad XVII M, kegagalan Anakkoda Bonang mendorong Raja Aceh mengutus tiga mubalig dari Minangkabau, salah satunya Datuk ri Bandang untuk mengislamkan Raja Gowa dan Tallo. Dua tahun kemudian, yaitu tanggal 9 November 1607 M (10 Rajab 1016 H), rakyat Kerajaaan Makassar resmi menerima agama Islam dengan ditandai sholat Jumat pertama di Tallo; dan fase ketiga: setelah Kerajaan Gowa menerima agama Islam, pendidikan dan pengajaran Islam selanjutnya dipusatkan di daerah Bontoala oleh Datuk ri Bandang bersama Sayyid Ba'Alwy.

\section{UCAPAN TERIMA KASIH}

Terima kasih kepada Kepala Balai Arkeologi Makassar karena telah memprogramkan kegiatan penelitian arkeologi di wilayah Kerajaan GowaTallo tahun 2013-2014. Terima kasih kepada para anggota tim penelitian arkeologi di wilayah Kerajaan Gowa-Tallo tahun 2013-2014. Kepada Drs. Mukhlis Hadrawi yang telah menerjemahkan naskahnaskah lontara. Terima kasih kepada Bapak Haji Ince Muhammad Unais Hasan, Imam Masjid Makmur Melayu dan masyarakat Kota Makassar dan Kabupaten Gowa yang telah memberikan informasi tentang Kehadiran orang Melayu di wilayah Kerajaan Gowa-Tallo.

\section{DAFTAR PUSTAKA}

Ambary, Hasan Muarif. 1998. Menemukan Peradaban Jejak Arkeologis dan Historis Islam Indonesia. Jakarta: Logos

Andaya, Leonard Y. 2004. Warisan Arung Palakka: Sejarah Sulawesi Selatan Abad ke-17. Makassar: Ininnawa

Anonim. 2009. Cetak Panrita dari Bontoala, Salemo hingga Mangkoso?

A. Zainal AF. 1999. Sejarah Sulawesi Selatan. 
Makassar: Ininnawa.

Hamonic, Gilbert. 1985. La fête du grand Maulid à Cikoang, regard sur une tarekat dite "shî̀ite» en Pays Makassar. Archipel, Vol. 29, 1985. Pdf. Diterjemahkan oleh Supratman.

Harkantiningsih, Naniek. Dkk. 2008. Kerajaan Gowa-Tallo: Pusat Peradaban Abad XVIXIX. Pusat Arkeologi Nasional. Jakarta: Kementerian Pendidikan dan Kebudayaan

Maryaeni. 2005. Metode Penelitian Kebudayaan. Jakarta: Bumi Aksara.

Mahmud, M. Irfan. Dkk. 2006. Survei dan ekskavasi Situs Benteng Garassi Kabupaten Gowa Sulawesi Selatan. Balai Arkeologi Makassar. Makassar: Kementerian Pendidikan dan Kebudayaan

Mattulada. 1991. Menyusuri Jejak Kehadiran Makassar Dalam Sejarah (1510-1700). Ujung Pandang: Hasanuddin University Press.

Noorduyn J. 1964. Sejarah Agama Islam di SulawesiSelatan. Dalam W. B. Sidjabat (ed.). Panggilan Kita di Indonesia Dewasa Ini. Jakarta: Badan Penerbit Keristen

Pelras, C. 2010. Migrasi ke Kerajaan Johor (Melayu) dari Akhir Abad ke-19 hingga tahun 1950-an: Proses dan Faktor Kultural dan Keagamaan dalam Asimilasi dengan Melayu. Dalam Andi Faisal Bakti (ed). Diaspora Bugis di Alam Melayu Nusantara. Makassar: Ininnawa.
Poelinggomang, E. L, Suriadi M, Daud L, Syahrul A, dan Sahajuddin. (2004). Sejarah Sulawesi Selatan Jilid 1. Makassar: Badan Penelitian dan Pengembangan Daerah (Balitbangda).

Poelinggomang, E. L. (2002). Makassar Abad XIX: Studi Tentang Kebijakan Perdagangan Maritim. Jakarta: Kepustakaan Populer Gramedia

Poesponegoro, M. D dan Nugroho N. 1993. Sejarah Nasional Indonesia IV. Jakarta: Balai Pustaka.

Rosmawati, 2013. Perkembangan Tamadun Islam di Sulawesi Selatan, Indonesia: Dari Perspektif Arkeologi Dan Sejarah. Disertasi. Universiti Sains Malaysia.

Ricklefs, M.C. 2008. Sejarah Indonesia Modern. Yogyakarta: Gadjah Mada University Press.

Sewang, M. Ahmad. 2005. Islamisasi Kerajaan Makassar, Abad XVI Sampai Abad XVII. Jakarta: Yayasan Obor Indonesia.

Sewang, M. Ahmad. 2007. Empat Abad Islam di Sulawesi Selatan. Makalah. Seminar Internasional dan Festival Kebudayaan. Pusat Kajian Islam (Centre for Middle Eastern Studies) Divisi Ilmu-Ilmu Sosial dan Humaniora PKP Unhas dan Pemkot Makassar.

Soekmono. 2006. Sejarah Kebudayaan Indonesia 3. Yogyakarta: Kanisius.

Zuhri, H.S. 1979. Sejarah Kebangkitan Islam dan Perkembangannya di Indonesia. Bandung: Almaarif. 